\title{
Laporan kasus berbasis bukti Penundaan Penjepitan Tali Pusat pada Bayi Baru Lahir Cukup Bulan
}

\author{
Sorayah Agustini, Rosalina D. Roeslani \\ Departemen Ilmu Kesehatan Anak Fakultas Kedokteran Universitas Indonesia/ RS Dr. Cipto Mangunkusumo, Jakarta
}

Latar belakang. Penundaan penjepitan tali pusat selain dapat meningkatkan cadangan zat besi, juga dapat meningkatkan transfer sel induk (stem cells) ke bayi. Penundaan penjepitan tali pusat pada bayi kurang bulan dapat mengurangi kebutuhan transfusi darah, mencegah intraventricular haemorrage (IVH), dan mencegah hipotensi

Tujuan. Mengetahui pengaruh penundaan penjepitan tali pusat pada bayi baru lahir cukup bulan untuk mencegah anemia dan meningkatkan cadangan besi.

Metode. Penelusuran pustaka database elektronik, yaitu Pubmed, Cochrane, Highwire.

Hasil. Terdapat tiga meta-analisis yang relevan dengan permasalahan. Penjepitan tali pusat tunda dilakukan minimal dua menit setelah bayi lahir, sedangkan penjepitan tali pusat dini dilakukan segera setelah lahir. Didapatkan rerata Hb bayi dengan penjepitan tali pusat tunda lebih tinggi dibanding penjepitan dini pada usia tujuh jam (WMD 0,6 g/dL; IK95\% 0,11-1,09) dan usia 3 bulan (weighted mean difference $=$ WMD 1,1 g/dL; IK95\% 0,66-1,54). Perbedaan rerata Hb ini tidak bermakna pada usia enam bulan ${ }^{11}$ (WMD $0 \mathrm{~g} / \mathrm{dL}$; IK 95\% 0,21- 0,21). Risiko bayi dengan penjepitan tali pusat tunda mengalami anemia lebih rendah dibanding bayi dengan penjepitan dini pada usia 24 sampai 48 jam (relative risk=RR 0,2; IK 95\% 0,06 -0,66). Bayi dengan penjepitan tali pusat tunda memiliki peningkatan kadar feritin (MD 17 mcg/L; IK95\% 12,15-21,85) dibandingkan penjepitan dini. Penundaan penjepitan tali pusat dapat meningkatkan kadar $\mathrm{Hb}$ usia 24 sampai 48 jam dan cadangan besi bayi sampai usia enam bulan.

Kesimpulan. Pada bayi cukup bulan penundaan penjepitan tali pusat satu sampai tiga menit setelah lahir dapat mencegah anemia sampai usia dua bulan dan meningkatkan cadangan besi sampai usia enam bulan. Risiko yang dapat terjadi, yaitu hiperbilirubinemia dan polisitemia, walaupun tidak terbukti menimbulkan kondisi yang membahayakan. Sari Pediatri 2016;17(5):384-90.

Kata kunci: penjepitan tali pusat, anemia, $\mathrm{Hb}$, cadangan besi

\section{Evidence base case report Delayed Clamping of Umbilical Cord in Term Baby}

Sorayah Agustini, Rosalina D. Roeslani

Background. Delayed umbilical cord clamping in all births is associated with many neonatal benefits, including increased blood volume, reduced need for blood transfusion, decreased incidence of intraventricular hemorrhage and prevention of hypotention. Objective. To know the role of delayed umbilical cord clamping in term-baby in preventing the incidence of anemia and to increase the iron deposit.

Methods. Literature search using electronic database, Pubmed, Cochrane Library and Highwire with key words "early or delay", "cord clamp", "term infants", "anemia or iron or hyperbilirubinemia or polycythemia"

Results. There are three meta-analysis regarding delayed umbilical cord clamping. The babies with delayed umbilical cord clamping for 2 minutes had higher mean $\mathrm{Hb}$ compare to those with early clamping (Weight Mean Difference/WMD 0,6 g/dL; 95\% CI 0,11-1,09) at 3 months of age (WMD 1,1 g/dL; CI 95\% 0,66-1,54). The risk for having anemia was smaller in babies with delayed cord clamping at $24-48$ hours (relative risk [RR], 0,2; 95\% CI 0,06 -0,66) and ferritin level was within normal limitsat age 6 month as well.

Conclusion. In term newborn infants, cord clamping at 1 or 3 minutes after birth resulted in prevention of anemia until 2 moths of age and increased body iron storage for 6 months. The risk of hyperbilirubinemia and polycythemia could occur without any harmful effects. Sari Pediatri 2016;17(5):384-90.

Keywords: umbilical cord clamping, anemia, $\mathrm{Hb}$, iron store

Alamat korespondensi: Dr. Rosalina Dewi Roeslani, SpA(K). Departemen Ilmu Kesehatan Anak Fakultas Kedokteran Universitas Indonesia/ RS Dr. Cipto Mangunkusumo. Jl. Salemba 6, Jakarta. E-mail: rosiroeslani@idai.or.id, rosiroeslani@gmail.com 
W aktu penjepitan tali pusat memegang peran penting dalam menentukan kecukupan zat besi pada bayi baru lahir. Saat dalam kandungan, janin berhubungan dengan ibu melalui tali pusat yang merupakan bagian dari plasenta. Sekitar 25\% sampai $60 \%$ volume darah fetoplacental berada dalam plasenta, yang dialirkan ke bayi sampai dengan tali pusat berhenti berdenyut (disebut transfusi plasenta). Transfusi plasenta yang berhubungan dengan penundaan penjepitan tali pusat dapat menambah $30 \%$ volume darah dan $60 \%$ sel darah merah. Jumlah eritrosit dan hemoglobin yang cukup selanjutnya dapat dijadikan sumber zat besi bagi bayi. ${ }^{1}$

Panduan asuhan persalinan normal (APN) di Indonesia tidak jelas menetapkan kapan waktu penjepitan tali pusat yang paling optimal bagi ibu dan bayi. ${ }^{2}$ World Health Organization (WHO) tahun 2012 merekomendasikan penjepitan tali pusat satu sampai tiga menit setelah lahir untuk pencegahan perdarahan pasca melahirkan. ${ }^{5}$ Berdasarkan Guideline of Basic Newborn Resuscitation tahun 2012 WHO juga merekomendasikan penjepitan tali pusat setelah satu menit pada neonatus cukup bulan (NCB) dan neonatus kurang bulan (NKB) yang tidak membutuhkan ventilasi tekanan positif segera. ${ }^{3}$

Penundaan penjepitan tali pusat selain dapat meningkatkan cadangan zat besi, juga dapat meningkatkan transfer sel induk (stem cells) ke bayi. ${ }^{4}$ Penundaan penjepitan tali pusat pada bayi kurang bulan dapat mengurangi kebutuhan transfusi darah, mencegah intraventricular haemorrage (IVH), dan mencegah hipotensi. ${ }^{5}$ Dampak yang berbeda pada bayi cukup bulan dan kurang bulan menyebabkan beberapa penelitian membedakan pembahasan keduanya. Sajian kasus berbasis bukti ini membahas pengaruh penundaan penjepitan tali pusat pada bayi baru lahir cukup bulan (usia gestasi $\geq 37$ minggu).

\section{Kasus}

Seorang bayi perempuan lahir spontan di Instalasi Gawat Darurat (IGD) Rumah Sakit Cipto Mangunkusumo (RSCM) dengan berat lahir 2900 gram dan usia gestasi 38 minggu. Ibu pasien dirujuk dari Puskesmas dengan keterangan ketuban berkurang dan belum in-partu. Tidak dilaporkan faktor risiko infeksi ibu seperti demam, nyeri buang air kecil (BAK) dan keputihan. Saat lahir bayi langsung menangis (skor Apgar 9/10), bayi diletakkan di atas perut ibu, dikeringkan dan diselimuti kain hangat. Usia satu menit tali pusat dijepit dan dipotong. Bayi kemudian dibawa ke infant warmer, disuntikkan vitamin $\mathrm{K}$ dan dilakukan inisiasi menyusui dini (IMD).

Pemeriksaan fisis pasien tampak aktif, tidak sesak dan tidak sianosis. Pada status generalis didapatkan lingkar kepala $34 \mathrm{~cm}$, konjungtiva tidak pucat dan tidak ikterik. Pemeriksaan paru, jantung dan abdomen dalam batas normal. Akral hangat dan perfusi perifer baik. Skor Balard sesuai dengan umur kehamilan 38 minggu. Usia delapan jam dilakukan pemeriksaan darah perifer, didapatkan $\mathrm{Hb}$ $18 \mathrm{~g} / \mathrm{dL}$, hematokrit (Ht) 55\%, jumlah leukosit 18000/ $\mu \mathrm{L}$ dan jumlah trombosit $248000 / \mu \mathrm{L}$.

Pasien dirawat gabung bersama ibu dan diberikan air susu ibu (ASI) ad libitum. Selama pemantauan di ruang rawat gabung bayi aktif, tidak sesak, toleransi minum baik dan tidak tampak kuning. Usia dua hari pasien dipulangkan dari RSCM.

\section{Metode penelusuran literatur}

Untuk menjawab permasalahan yang diajukan, dilakukan penelusuran pustaka secara on-line dengan mempergunakan instrumen pencari Pubmed, Cochrane Library, dan Highwire. Kata kunci yang digunakan adalah (early or delay*) AND (cord clamp*) AND (term infants) AND (anemia or iron or hyperbilirubinemia or polycythemia). Batasan yang digunakan ialah studi yang dilakukan pada manusia, bahasa pengantar dalam bahasa Inggris, publikasi dalam sepuluh tahun terakhir serta jenis publikasi berupa uji klinis, uji klinis terandomisasi, telaah sistematis dan meta-analisis.

Penelusuran literatur dengan metode tersebut menghasilkan tiga meta-analisis. Telaah kritis dilakukan pada tiga artikel terpilih untuk menentukan apakah artikel tersebut sahih, penting dan dapat diterapkan pada pasien. Penentuan levels of evidence (LoE) berdasarkan pada klasifikasi yang dikeluarkan oleh Oxford Centre for Evidence-Based Medicine. ${ }^{6}$

\section{Hasil}

\section{Studi meta-analisis (level of evidence I)}

1. Penjepitan tali pusat tunda dilakukan minimal dua menit setelah bayi lahir ( $\mathrm{n}=1001$ bayi), sedangkan 
penjepitan tali pusat dini ( $\mathrm{n}=911$ bayi) dilakukan segera setelah lahir. ${ }^{7}$ Rerata Ht bayi usia 6 jam dengan penjepitan tali pusat tunda lebih tinggi dibandingkan penjepitan tali pusat dini ${ }^{8,9}$ WMD 4,16\%; IK95\% 0,83\%-7,49\%).7 Perbedaan Ht ini juga didapatkan sampai usia 24 sampai 48 jam ${ }^{9}$ (WMD, 10,01\%; IK95\% 4,1\%-15,92\%)7, usia lima hari ${ }^{10-13}$ (WMD 11,97\%, IK 95\% 8,5\%$15,45 \%)^{7}$ dan usia dua bulan ${ }^{18}$ (WMD 3,7\%, IK 95\% 2\%- 5,4\%). Perbedaan hematokrit yang bermakna ini tidak didapatkan pada usia enam bulan $^{8}$ (WMD 0,1\%; IK 95\% 0,62\% - 0,82\%).

Rerata $\mathrm{Hb}$ bayi dengan penjepitan tali pusat tunda lebih tinggi dibanding penjepitan tali pusat dini pada usia tujuh jam ${ }^{11}$ (WMD 0,6 g/dL; IK95\% 0,11-1,09) dan usia 3 bulan $^{19}$ (WMD 1,1 g/dL; IK95\% 0,66 -1,54). Perbedaan rerata Hb ini tidak bermakna pada usia enam bulan ${ }^{8}$ (WMD 0 g/dL; IK 95\% 0,21- 0,21). Sedangkan kadar serum bilirubin tidak berbeda bermakna antara bayi $95 \%$ 2,47-39). ${ }^{7}$

Risiko bayi dengan penjepitan tali pusat tunda mengalami anemia lebih rendah dibanding bayi dengan penjepitan tali pusat dini pada usia 24 sampai 48 jam $^{9}$ (RR, 0,2; IK95\% 0,06 -0,66) ${ }^{10}$ dan pada usia dua sampai tiga bulan ${ }^{14,18}$ (RR 0,53; IK 95\% 0,4 - 0,7 7 dengan number needed to treat (NNT) tiga. Pada usia enam bulan, proporsi anemia pada bayi dengan penjepitan tali pusat tunda dan dini sama ${ }^{8}$ (RR 0,85; IK95\% 0,51- 1,43). ${ }^{7}$ Bayi dengan penjepitan tali pusat tunda memiliki rerata ferritin $46,7 \mu \mathrm{g} / \mathrm{L}$, sedangkan penjepitan tali pusat dini $34,9 \mu \mathrm{g} / \mathrm{L}(\mathrm{p}=0,001)$. Defisiensi besi pada bayi dengan penjepitan tali pusat dini $(\mathrm{n}=154)$ terdapat pada 12 bayi, sedangkan bayi dengan penjepitan tali pusat tunda terdapat tiga bayi ( $\mathrm{n}=161)$ yang mengalami defisiensi besi ( $R R$ 3,665; IK95\% 1,2- 11,3, NNT=16). ${ }^{8}$

Risiko ikterik antara bayi dengan penjepitan tali pusat tunda dan dini tidak berbeda bermakna pada usia 24 sampai 48 jam kehidupan ${ }^{9,15,16,19}$ (RR 1,16; IK95\% 0,85-1,58) dan pada tiga sampai 14 hari setelah lahir ${ }^{8}$ (RR 1,27; IK95\% 0,76 - 2,10) dengan number needed to harm (NNH) sebanyak 22 bayi. Risiko bayi ikterik yang membutuhkan terapi sinar antara penjepitan tali pusat tunda dan dini tidak berbeda secara statistik (RR 1,78; IK95\% 0,71-4,46) dengan NNH 63 bayi. Terdapat peningkatan risiko terjadinya polisitemia asimtomatik pada bayi dengan penjepitan tali pusat tunda, ${ }^{9}$ (RR 3,91; IK95\% 1,00-15,36) ${ }^{7}$ dengan NNH 22 bayi, namun secara statistik tidak bermakna. Risiko sesak nafas dan perawatan NICU juga tidak didapatkan perbedaan bermakna antara bayi dengan penjepitan tali pusat tunda dan dini. Disimpulkan penundaan penjepitan tali pusat minimal dua menit setelah lahir dapat mencegah anemia dua sampai tiga bulan dan meningkatkan cadangan besi sampai usia enam bulan.

2. Meta-analisis pada tahun 2011 dilakukan terhadap uji klinis acak terkontrol yang membanding penjepitan tali pusat tunda (lebih dari 30 detik sejak lahir) dengan penjepitan tali pusat dini (kurang dari 30 detik sejak lahir) pada bayi cukup bulan (usia gestasi lebih dari 37 minggu) dan kurang bulan. ${ }^{20}$ Didapatkan bahwa bayi dengan penjepitan tali pusat tunda dibandingkan dini memiliki peningkatan rerata $\mathrm{Ht}$ saat lahir (enam studi, mean difference $=$ MD 2,38\%; IK95\% 1,103,67 ), peningkatan rerata $\mathrm{Hb}$ saat lahir (MD 1,95g/dL; IK95\% 0,81-3,10), peningkatan kadar ferritin (MD $17 \mathrm{mcg} / \mathrm{L}$; IK95\% 12,15-21,85). Tidak terdapat perbedaan bermakna pada luaran yang lain (rerata $\mathrm{Ht}, \mathrm{Hb}$ dan anemia pada saat pemantauan, risiko hiperbilirubinemia, kebutuhan terapi sinar, polisitemia, distres pernafasan, dan perdarahan ibu pasca-melahirkan). Disimpulkan bahwa penundaan penjepitan tali pusat pada bayi cukup bulan memberikan manfaat yang terbatas terhadap bayi dan tidak meningkatkan komplikasi atau memberikan manfaat terhadap ibu.

3. Meta-analisis pada tahun 2013 oleh Mc Donald $\mathrm{dkk}^{21}$ terhadap uji klinis acak terkontrol yang membandingkan penjepitan tali pusat tunda (lebih dari satu menit sejak lahir) dengan penjepitan tali pusat dini (kurang dari satu menit sejak lahir) pada bayi cukup bulan didapatkan 15 studi dengan 3911 pasang ibu dan bayi. Luaran yang dinilai meliputi luaran terhadap ibu dan bayi. Tidak terdapat studi yang melaporkan mortalitas maupun morbiditas terhadap ibu pada penundaan penjepitan tali pusat. Risiko perdarahan berat pasca-melahirkan antara penjepitan tali pusat dini dan tunda sama (risk ratio=RR 1,04; IK95\% 0,65-1,65; lima studi dengan 2066 ibu; NNH=500). Bayi dengan penjepitan tali pusat dini dibandingkan penjepitan tali 
pusat tunda tidak didapatkan perbedaan bermakna risiko mortalitas (RR 0,37; IK95\% 0,04 - 3,41; dua studi dengan 381 bayi; $\mathrm{NNH}=182$ ) maupun morbiditas seperti skor Apgar kurang dari tujuh usia lima menit (RR 1,23; IK95\% 0,73-2,07; tiga studi dengan 1399 bayi, $\mathrm{NNH}=112$ ), perawatan ke NICU (RR 0,79; IK95\% 0,48-1,31; empat studi dengan 1675 bayi; $\mathrm{NNH}=94)$ dan polisitemia (RR 0,39; IK95\% 0,12-1,27; NNH=55). Bayi dengan penjepitan tali pusat dini lebih sedikit membutuhkan terapi sinar dibandingkan bayi dengan penjepitan tali pusat tunda (RR 0,62; IK 95\% 0,41-0,96; tujuh studi dengan 2324 bayi; $\mathrm{NNH}=62) .{ }^{21}$

Kadar Hb bayi usia 24 sampai 48 jam lebih rendah pada bayi dengan penjepitan tali pusat dini (MD -1,49 g/dL; IK 95\% 1,78-1,21), namun perbedaan $\mathrm{Hb}$ ini tidak bermakna pada usia tiga sampai enam bulan. Bayi dengan penjepitan tali pusat dini memiliki risiko dua kali mengalami defisiensi besi pada usia tiga sampai enam bulan dibanding bayi dengan penjepitan tali pusat tunda (RR 2,65; IK 95\% 1,04-6,73; lima studi dengan 1152 bayi; NNT=17). Disimpulkan penundaan penjepitan tali pusat dapat meningkatkan kadar $\mathrm{Hb}$ usia 24 sampai 48 jam dan cadangan besi bayi sampai usia enam bulan. Penundaan penjepitann tali pusat bermanfaat selama terdapat fasilitas untuk terapi hiperbilirubinemia yang membutuhkan terapi sinar.

\section{Pembahasan}

Definisi penjepitan tali pusat dini bervariasi, mulai dari segera setelah lahir sampai dengan sebelum satu menit dengan rata-rata 10 sampai 30 detik setelah lahir. Definisi penjepitan tali pusat tunda juga bervariasi di antara beberapa penelitian. Definisi penundaan penjepitan tali pusat adalah penjepitan dua sampai tiga menit setelah lahir atau setelah pulsasi hilang. ${ }^{22}$ Sedangkan Cochrane meta-analisis mendefinisikan penundaan penjepitan tali pusat apabila penjepitan dilakukan lebih dari satu menit. ${ }^{21}$

Saat janin, dua pertiga sampai setengah volume darah fetal-placental berada dalam plasenta dan terjadi proses respirasi (pertukaran gas). Sedangkan sirkulasi pulmonal selama masa janin hanya mendapat $8 \%$ dari curah jantung. Selama proses kelahiran terdapat peningkatan drastis sirkulasi pulmonal yang membutuhkan 40\%-55\% dari curah jantung. Oleh karena itu diperlukan volume darah yang cukup agar perfusi organ vital lainnya tetap adekuat. Kontraksi uterus selama persalinan menyebabkan kompresi plasenta dan terjadi transfer darah dari plasenta menuju janin yang dapat meningkatkan tekanan dan volume darah sehingga meningkatkan perfusi seluruh tubuh termasuk paru. Peningkatan perfusi paru menyebabkan capillary erection pada kapiler dan menarik cairan dari alveolus melalui membran kapiler sehingga udara dapat masuk dengan mudah. Jika volume darah yang dialirkan dari plasenta tidak adekuat (seperti pada penjepitan tali pusat dini), maka bayi akan mengambil darah dari organ lain sehingga dapat mengakibatkan hipoperfusi organ tersebut. Sebaliknya, pada penjepitan tali pusat tunda, tali pusat yang tidak dijepit memungkinkan peningkatan volume darah, kadar oksigen dan keseimbangan $\mathrm{pH}$. Peningkatan sel darah merah dan peningkatan kadar oksigen darah dapat menstimulasi pusat respirasi untuk memulai bernapas. ${ }^{23}$

Perkiraan volume darah total janin dan plasenta $105-110 \mathrm{ml} / \mathrm{kg}$. Penelitian yang dilakukan Yao dkk ${ }^{24}$ menunjukkan bahwa pada bayi cukup bulan, penjepitan tali pusat dalam satu menit akan mentransfusikan sekitar 50\% volume plasenta. Apabila penjepitan tali pusat ditunda sampai dengan tiga menit, maka dapat memberikan tambahan $20-35 \mathrm{ml} / \mathrm{kg}$ (gambar 1). Penambahan volume darah ini akan meningkatkan hemoglobin dan hematokrit bayi baru lahir. Hal tersebut dibuktikan dalam hasil tiga meta-analisis di atas bahwa nilai hemoglobin dan hematokrit saat lahir sampai usia dua bulan lebih tinggi secara bermakna pada bayi yang dilakukan penundaan penjepitan tali pusat dibandingkan dengan bayi yang dilakukan penjepitan tali pusat dini. ${ }^{17,20,21}$ Dengan demikian penundaan penjepitan tali pusat dapat secara bermakna menurunkan risiko terjadi anemia. Meta-analisis yang dilakukan Hutton $\mathrm{dkk}^{7}$ menunjukkan penurunan bermakna risiko anemia sampai usia 2-3 bulan pada bayi dengan penundaan penjepitan tali pusat.

Perbedaan rerata $\mathrm{Hb}$ yang bermakna antara bayi dengan penjepitan tali pusat dini dan tunda tidak dijumpai saat usia 6 bulan. ${ }^{7,21}$ Namun beberapa studi masih menunjukkan peningkatan status besi bayi dengan penundaan penjepitan tali pusat sampai usia enam bulan. ${ }^{7,20,21} \mathrm{Hal}$ tersebut perlu diperhatikan karena kadar $\mathrm{Hb}$ belum terpengaruh sampai dengan 
cadangan besi menurun. Penundaan penjepitan tali pusat selama tiga menit memberikan tambahan 100 $\mathrm{ml}$ volume darah. Volume darah tersebut dapat menambah $40-50 \mathrm{mg} / \mathrm{kg}$ besi ke dalam $75 \mathrm{mg} / \mathrm{kg}$ besi yang telah ada pada tubuh bayi baru lahir cukup bulan, sehingga total besi sekitar 115-120 mg/kg. Maka

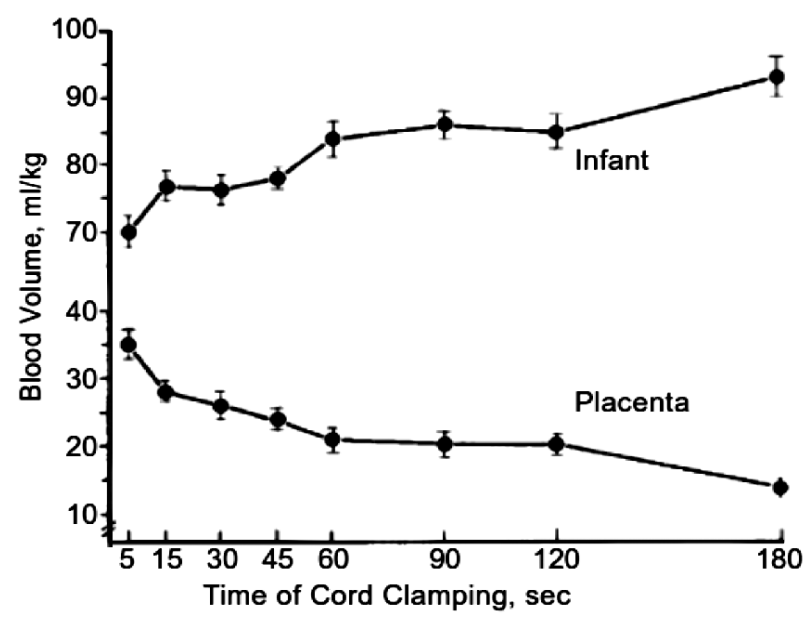

Gambar 1. Distribusi antara volume darah bayi dan residu plasenta pada berbagai waktu penjepitan tali pusat.

Dikutip dari Yao A, Moinian M, Lind J. Lancet. 1969;2:871-3. 24

dengan penambahan jumlah tersebut dapat mencegah defisiensi besi sampai dengan satu tahun kehidupan.

Kasus yang disajikan adalah bayi baru lahir cukup bulan yang dilakukan penundaan penjepitan tali pusat selama satu menit. Keadaan klinis pasien selama pemantauan di rumah sakit (sampai dengan usia dua hari) aktif, tanda vital stabil dan tidak didapatkan ikterik. Usia delapan jam pasien dilakukan pemeriksaan darah rutin, didapatkan $\mathrm{Hb} 18 \mathrm{~g} / \mathrm{dL}$ dan Ht 55\%. Hasil ini sesuai dengan penelitian Chaparro $\mathrm{dkk}^{8}$ bahwa bayi dengan penjepitan tali pusat tunda memiiliki rerata $\mathrm{Hb} 19,9 \mathrm{~g} / \mathrm{dL}( \pm 2,4)$ dan rerata $\mathrm{Ht}$ $62 \%( \pm 7,5)$.

Penundaaan penjepitan tali pusat memfasilitasi aliran darah lebih banyak ke bayi sehingga jumlah eritrosit yang masuk juga lebih banyak dan berisiko terjadi polisitemia. Polisitemia didefinisikan apabila Ht $>65 \%$ dan terjadi pada $2 \%$ sampai $5 \%$ bayi baru lahir. Terapi polisitemia ditentukan oleh peningkatan kadar Ht disertai dengan gejala letargis, sesak, sianosis, takikardia, kejang, dan gangguan fungsi ginjal. Metaanalisis yang dilakukan oleh Hutton $\mathrm{dkk}^{7}$ menunjuk- kan bahwa bayi dengan penundaan penjepitan tali pusat memiliki risiko polisitemia usia tujuh jam dan 24 sampai 48 jam. Namun tidak ada di antara bayi yang mengalami polisitemia menunjukkan gejala atau membutuhkan terapi. Apabila studi yang diambil hanya studi dengan kualitas yang tinggi (dua studi) maka risiko polisitemia secara statistik tidak bermakna. Meta-analisis yang dilakukan oleh McDonald dkk ${ }^{21}$ dan Mathew ${ }^{20}$ juga mendapatkan peningkatan risiko polisitemia namun tidak bermakna secara statistik.

Komplikasi kehamilan seperti preeklamsia atau eklamsia, diabetes melitus pada ibu, janin besar atau kecil masa kehamilan, dan kelainan genetik lainnya meningkatkan risiko polisitemia pada bayi. Hipoksia akan menginduksi gangguan integritas endotel pembuluh darah, sehingga terjadi kebocoran kapiler dan menyebabkan komponen plasma (garam, air, albumin) keluar ke dalam ruang ekstravaskular. Kondisi tersebut mengakibatkan hemokonsentrasi. Oleh karena itu peningkatan risiko polisitemia dihubungkan dengan kondisi hipoksia yang mendasari. ${ }^{23}$

Penambahan eritrosit pada penjepitan tali pusat tunda dapat meningkatkan produksi bilirubin sehingga meningkatkan risiko hiperbilirubinemia. Meta-analisis yang dilakukan oleh Hutton $\mathrm{dkk}^{7}$ menunjukkan bahwa tidak terdapat perbedaan bermakna rerata kadar bilirubin maupun peningkatan risiko ikterik pada usia tiga hari sampai dengan 14 hari pada bayi dengan penundaan penjepitan tali pusat. Meta-analisis yang dilakukan oleh McDonald dkk. ${ }^{21}$ menunjukkan bahwa bayi dengan penjepitan tali pusat dini lebih sedikit membutuhkan terapi sinar dibandingkan bayi dengan penjepitan tali pusat tunda (RR 0,62; IK 95\% 0,41-0,96 pada tujuh studi dengan 2324 bayi, $\mathrm{NNH}=62$ ), dan di antara bayi tersebut tidak ada yang membutuhkan transfusi tukar maupun perawatan di NICU. Perbedaan hasil tersebut masih mungkin diakibatkan perbedaan batasan kadar bilirubin untuk terapi sinar.

Pengaruh penundaan penjepitan tali pusat terhadap morbiditas lain seperti distres napas dan perawatan di neonatal intensive care unit (NICU) menunjukkan tidak ada perbedaan antara bayi dengan penjepitan tali pusat dini dan tunda. Penelitian yang dilakukan Cernadas $\mathrm{dkk}^{9}$ menunjukkan bayi dengan penundaan penjepitan tali pusat mengalami sedikit peningkatan laju napas, namun tidak membutuhkan terapi respirasi tambahan. Penelitian oleh McDonald $\mathrm{dkk}^{21}$ menunjukkan tidak ada perbedaan bayi yang membutuhkan perawatan 
NICU karena distres napas antara penjepitan tali pusat dini dan tunda.

Darah tali pusat manusia mengandung banyak sel induk (stem cell) pluripoten, seperti sel induk hematopoietik, prekusor sel endotelial, progenitor mesenkimal, dan pluripoten/ multipoten lineage stem cells. Transfusi darah dari plasenta ke bayi tidak hanya memberikan tambahan volume darah untuk stabilisasi sistem sirkulasi dan meningkatkan cadangan besi, namun juga memberikan sel induk yang penting bagi perkembangan dan maturitas beberapa sistem organ, termasuk sistem saraf pusat, respirasi, kardiovaskular, hematologi, imunologi, dan sistem endokrin sejak janin dalam kandungan. Maturasi setiap sistem organ ini masih berlanjut sampai masa neonatal, sehingga kehilangan sel induk saat proses kelahiran dapat berpotensi mengganggu perkembangan selanjutnya dan menjadi predisposisi penyakit pada bayi. ${ }^{4}$ Transfer sel induk pada penundaan penjepitan tali pusat diharapkan dapat mencegah beberapa kelainan darah dan kondisi imun.

Jumlah dan lama aliran darah dari plasenta ke bayi dipengaruhi oleh beberapa faktor seperti kontraksi uterus, pemberian oksitosin, dan gravitasi. Kontraksi uterus pada keadaan normal terjadi satu sampai tiga menit setelah bayi lahir dapat mempercepat transfer darah dari plasenta ke bayi. Penyuntikkan oksitosin segera setelah bayi lahir pada pelaksanaan manajemen aktif kala tiga dapat mempercepat kontraksi uterus. Gravitasi juga memiliki peran dalam jumlah dan kecepatan transfer darah dari plasenta ke bayi. Van Rheenen dkk. ${ }^{25}$ dalam penelitiannya merekomendasikan posisi bayi antara $10 \mathrm{~cm}$ di atas dan $10 \mathrm{~cm}$ di bawah ketinggian plasenta untuk memungkinkan transfusi yang optimal dalam tiga menit dan posisi bayi $40 \mathrm{~cm}$ di bawah plasenta dapat mempersingkat waktu menjadi satu menit. Levy dan Blickstein $^{26}$ juga merekomendasikan bayi diletakkan setinggi atau di bawah plasenta untuk memungkinkan gravitasi mentransfusikan darah melalui tali pusat.

\section{Kesimpulan}

Penundaan penjepitan tali pusat satu sampai tiga menit setelah lahir dapat mencegah anemia sampai usia dua bulan dan meningkatkan cadangan besi sampai usia enam bulan. Penundaan penjepitan tali pusat dapat menjadi strategi yang murah dan efektif untuk menurunkan anemia defisiensi besi dan meningkatkan kualitas hidup bayi di negara berkembang. Risiko yang dapat terjadi yaitu hiperbilirubinemia dan polisitemia, walaupun tidak terbukti menimbulkan kondisi yang membahayakan.

\section{Saran}

Penundaan penjepitan tali pusat satu sampai tiga menit dapat dipertimbangkan pada bayi baru lahir cukup bulan (usia gestasi $\geq 37$ minggu dan berat lahir $\geq 2500 \mathrm{~g}$ ) dengan klinis bugar dan tidak membutuhkan resusitasi segera. Penundaan penjepitan tali pusat sebaiknya dilakukan oleh tenaga medis yang memiliki keterampilan resusitasi neonatus dan mampu mengenali serta menangani komplikasi dengan fasilitas yang memadai.

\section{Daftar pustaka}

1. Eichenbaum-Pikser G, Zasloff JS. Delayed clamping of the umbilical cord: a review with implications for practice. J Midwifery Womens Health 2009;54:321-6.

2. Wiknjosastro G, Adriaansz G, Madjid AO, Santoso BI P. Asuhan persalinan normal. Jakarta: JNPK-KR; 2007.

3. World Health Organization. Guidelines on basic newborn resuscitation 2012. Diakses tanggal 5 November 2014. Diunduh dari: www.who.int.

4. Tolosa JN, Park DH, Eve DJ, Klasko SK, Borlongan CV, Sanberg PR. Mankind's first natural stem cell transplant. J Cell Mol Med 2010;14:488-95.

5. Rabe H, Reynolds G, Diaz-Rosello J. Early versus delayed umbilical cord clamping in preterm infants (review). Cochrane Database Syst Rev 2007;4:1-26.

6. Oxford Centre of Evidence-Based Medicine 2011 Levels of Evidence. Diakses pada tanggal 26 Oktober 2014. Diunduh dari http://www.ebcm.net/index.aspx? $0=5653$.

7. Hutton EK, Hassan ES. Late vs early clamping of the umbilical cord in full-term neonates: systematic review and meta-analysis of controlled trials. JAMA 2007;297:1241-52.

8. Chaparro CM, Neufeld LM, Alavez GT, Cedillo RE, Dewey KG. Effect of timing of umbilical cord clamping on iron status in Mexican infants : a randomised controlled trial. Lancet 1997;367:1997-2004.

9. Cernadas JMC, Carroli G, Pellegrini L, Otaño L, Ferreira M, Ricci C, dkk. The effect of timing of cord 
clamping on neonatal venous hematocrit values and clinical outcome at term: a randomized controlled trial. Pediatrics 2006;117:e779-86.

10. Abdel Aziz SF, Shaheen MY, Hussein S, Suliman MS. Early cord clamping and its effect on some hematological determinants of blood viscosity in neonates. Diakses tanggal 27 Oktober 2014. Diunduh dari: http://www. obgyn.net/pblarticles/cordclamping_aziz_0699.htm.

11. Nelle M, Zilow EP, Kraus M, Bastert G, Linderkamp O. The effect of leboyer delivery on blood viscosity and other hemorheologic parameters in term neonates. Am J Obstet Gynecol 1993;169:189-93.

12. Nelle M, Kraus M, Basiert G, Linderkamp O. Effects of leboyer childbirth on left- and right systolic time intervals in healthy term neonates. J Perinat Med 1996;24:51320.

13. Linderkamp O, Nelle M, Kraus M, Zilow EP. The effect of early and late cord-clamping on blood viscosity and other hemorheological parameters in full-term neonates. Acta Paediatr 1992;81:745-50.

14. Grajeda R, Perez-Escamila R, Dewey KG. Delayed clamping of the umbilical cord improves hematologic status of Guatemalan infants at 2 mo of age. J Clin Nutr 1997;65:425-31.

15. Emhamed MO, Van Rheene P, Brabin BJ. The early effects of delayed cord clamping in term infants born to Libyan mothers. Trop Doct 2004;34:218-22.

16. Oxford Midwives Research Group. A study of the relationship between the delivery to cord clamping interval and the time of cord separation. Midwifery
1991;7:167-76.

17. Saigal S, O’Neill A, Surainder Y, Chua L, Usher R. Plecental transfusion and hyperbilirubinemia in the premature. Pediatrics. 1972;49;406-19.

18. Gupta R RS. Effect of delayed cord clamping on iron stores in infants born to anemic mothers: a randomized controlled trial. Indian Pediatr 2002;39:130-5.

19. Nelson NM, Enkin M, Saigal S, Bennett, Milner R SD. A randomized clinical trial of the leboyer aproach to childbirth. N Engl J Med 1980;302:655-60.

20. Mathew JL. Timing of umbilical cord clamping in term and preterm deliveries and infant and maternal outcomes : a systematic review of randomized controlled trials. Indian Pediatr 2011;48:123-9.

21. McDonald SJ, Middleton P, Dowswell T, Morris PS. Effect of timing of umbilical cord clamping of term infants on maternal and neonatal outcomes (review). Cochrane Database Syst Rev 2013;7:1-80.

22. Andersson OLA. Effects of delayed versus early cord clamping on healthy term infants. Acta Univ Ups 2013;893:1-59

23. Mercer JS, Skovgaard RL. Neonatal transitional physiology. J Perinat Neonatal Nurs. 2002;15:56-75.

24. Yao A, Moinian M, Lind J. Distribution of blood between infant and placenta after birth. Lancet 1969;2:871-3.

25. Van Rheenen PF, Brabin BJ. A practical approach to timing cord clamping in resource poor settings. Br Med J 2006;333:954-8.

26. Levy T, Blickstein I. Timing of cord clamping revisited. J Perinatal Med 2006;34:293-7. 